\title{
CARREIRA E FAMÍLIA NA SOCIEDADE LÍQUIDO-MODERNA
}

ANDREA POLETO OLTRAMARI

Doutora em Administração pelo Programa de Pós-Graduação em Administração da Universidade Federal do Rio Grande do Sul (UFRGS).

Professora do Departamento de Administração da Universidade de Passo Fundo (UPF). BR 285, km 171, campus I, São José, Passo Fundo - RS - Brasil - CEP 99010-200

E-mail: andreaoltr@gmail.com

\section{CARMEM LIGIA IOCHINS GRISCI}

Doutora em Psicologia pelo Programa de Pós-Graduação em Psicologia da Pontifícia

Universidade Católica do Rio Grande do Sul (PUCRS).

Professora do Departamento de Administração da Universidade Federal do Rio Grande do Sul (UFRGS). Rua Washington Luís, 855, sala 424, Centro, Porto Alegre - RS - Brasil - CEP 90010-460

E-mail: cligrisci@ea.ufrgs.br 


\section{RESUMO}

Este artigo objetivou compreender como aqueles que compõem as relações familiares de executivos bancários percebem como estes enfrentam seus dilemas pessoais relativos à carreira, bem como analisar que estilos de vida resultam da condução da carreira de executivos bancários em contexto de trabalho imaterial. Para tanto, em termos teóricos e com o objetivo de sustentá-lo, trabalhou-se com os conceitos de dilema, de subjetividade e estilos de vida, modelos de carreira sem fronteira e proteana, além de trabalho imaterial. Foram entrevistados quatorze representantes das relações familiares de executivos bancários. As entrevistas estruturadas foram realizadas com os familiares em suas residências ou em estabelecimentos comerciais por eles indicados. A análise dos dados foi realizada de maneira qualitativa; os resultados indicaram dilemas relativos à mobilidade espacial e funcional, e à privação da convivência. A existência dos dilemas não se mostrou inédita, porém, na contemporaneidade, eles tomam a vida profissional e pessoal dos sujeitos independentemente de limites espaçotemporais, afetando o modo de viver do executivo bancário e de sua família. Esta configuração está relacionada a um "modelo" de carreira profissional meteórica, de responsabilidade única do próprio trabalhador, em um contexto em que prevalece o trabalho imaterial. Qualquer que seja a escolha do executivo e da família, ambos sofrem as consequências das suas decisões. Sob a metáfora da vida líquida, portanto, foi possível refletir acerca do tema da fluidez da existência e, assim, pensar a construção da carreira também a partir de trajetórias líquidas, fluidas, sinuosas. A metáfora da sinuosidade permitiu pensar que a construção da carreira pode ser incerta, insegura e vulnerável. Os resultados também apontaram a falta de convívio com a família, uma vez que ofertar tempo para os familiares seria deixar de estar nessa promissora rede de relacionamentos diretamente associada ao sucesso profissional. Assim, com base no olhar da família acerca dos dilemas vivenciados pelos executivos bancários, observaram-se estilos de vida que condizem com a vida líquida da sociedade líquido-moderna. 


\section{PALAVRAS=CHAVE}

Carreira. Dilemas. Executivo bancário. Relações familiares. Estilos de vida.

\section{INTRODUÇ ÃO}

Diante dos dilemas vivenciados por famílias de executivos bancários, observa-se que novas frentes de análise se abrem para os estudos sobre carreira, especialmente pela possibilidade que há em ampliar a compreensão de que o dilema relativo às escolhas profissionais de executivos não resultam tão somente suas, mas envolvem também os relacionamentos familiares.

$\mathrm{Na}$ Administração ainda são poucos os estudos que refletem sobre o olhar daqueles que sentem diretamente a repercussão das escolhas nas trajetórias das carreiras de executivos. Especificamente sobre carreiras, os estudos em Administração têm tido interface com os temas empregabilidade, expatriação, comprometimento, empreendedorismo, e se revestem de importância quando se referem a assuntos que dizem respeito a pessoas, especialmente quando se associam a estudos sobre equilíbrio entre vida pessoal e profissional. Os estudos sobre carreira na Administração mostram-se profícuos em pensar a carreira a partir do efêmero, de investimentos em novos rumos, tal como preconiza a vida líquida (Bauman, 2007a). A literatura internacional, especialmente nos modelos de carreira sem fronteira e proteana, como os de Sullivan e Arthur (2006), Briscoe e Hall (2006) e Hall (I996), aproxima carreira à noção de movimento, de investimento em si, que se associam à "vida como business" (Fontenelle, 2005; Sennett, 2006).

À luz do conceito de trabalho imaterial, o qual preconiza mobilização de si em prol do trabalho, da rentabilização do tempo e da vida como um todo, o indivíduo se exige mobilidade afetiva e espacial para garantir a concretude da sua carreira. Ao investir fortemente na carreira, um executivo passa a se responsabilizar cada vez mais por seu desempenho e também pelas consequências decorrentes dessa maior responsabilização. Tais consequências revertem-se diretamente na família.

O trabalho de um executivo adentra o tempo de vida pessoal e, portanto, o familiar. Para construírem suas carreiras, inevitavelmente, os executivos trabalham além do horário contratado, seja checando e-mails, fazendo ligações para clientes ou resolvendo mentalmente problemas constantemente pendentes.

As demandas por um outro trabalhador bancário, com um perfil diferente daquele que atendia às demandas anteriores às diversas formas de reestruturação que aconteceram no trabalho bancário, foram significativas. Isso interferiu na noção de carreira no banco que os bancários detinham e, por consequência, no 
modo de conduzi-la. Um registro abundante de trabalhos acerca do sofrimento psíquico é oferecido por Grisci (2008), Grisci, Hofmeister e Cigerza (2006), Grisci e Bessi (2004), Merlo e Barbarini (2002). Julga-se que o sofrimento psíquico acarretado à categoria em razão disso se associa às decisões relativas à carreira e suas repercussões nas relações familiares.

Alguns trabalhos têm incluído em suas análises certos condicionantes externos que repercutem na carreira dos sujeitos, como a necessidade de conciliar a vida profissional e a familiar (Dutra, 20ıо) e a perda da referência do país de origem quando os executivos são expatriados, indicando a existência de dificuldades (Zilio \& Dellagnello, 20Io). Contudo, não aprofundam a discussão a respeito da sobrecarga acarretada pela responsabilização única dos sujeitos por sua carreira, bem como não fazem referência aos possíveis dilemas que os profissionais vivenciam e às repercussões desses dilemas nas relações familiares.

Portanto, este artigo tem como objetivo analisar como aqueles que compõem as relações familiares de executivos bancários percebem como estes enfrentam os seus dilemas pessoais relativos à carreira, bem como analisar que estilos de vida resultam da condução da carreira de executivos bancários em contexto de trabalho imaterial.

Para responder a esses objetivos, o artigo está estruturado da seguinte forma: em que pese a revisão teórica, inicia-se com o trabalho imaterial e o executivo bancário; em seguida, trata de carreiras e de dilemas contemporâneos relativos à carreira nos estudos da Administração; finaliza-se com as carreiras na sociedade líquido-moderna. Apresentam-se os procedimentos metodológicos e, por fim, a análise dos resultados.

\section{TRABALHO IMATERIAL E O EXECUTIVO BANCÁRIO}

Com vista à construção de uma carreira, os trabalhadores bancários em geral vislumbram-se como executivos. A Administração tem definido o executivo como aquele que desempenha um papel gerencial que supervisiona as atividades de outros. Geralmente, os executivos passam a ser responsáveis pela realização das metas de desempenhos das empresas; por isso, suas responsabilidades são maiores. Tal fato também acontece com os executivos de instituições financeiras, que assumem uma carga de responsabilidade, especialmente por trabalharem com os investimentos financeiros de pessoas físicas e jurídicas. Desse modo, para construir suas carreiras, os executivos aumentam consideravelmente sua carga de trabalho, bem como suas responsabilidades. 
A instabilidade aliada à imprevisibilidade resultante das reestruturações no setor, das políticas de gerenciamento, bem como das novas tecnologias, conduziu o trabalho bancário a características de efemeridade. Para se manterem empregados diante da acirrada competição e da automatização que rouba a cena do trabalho manual e rotineiro, os trabalhadores bancários, especialmente os executivos, devem se manter mais intelectualizados e com competências diferenciadas, as quais são absolutamente distintas das demandadas anteriormente, nitidamente mais operacionais. Características como ter bom relacionamento com os clientes, ser agradável, estar à disposição 24 horas por dia juntam-se ao saber utilizar cálculos para prever os melhores resultados de investimentos, demonstrando a polivalência cada vez mais presente no trabalhador bancário (Segnini, I999).

Ano a ano, no Brasil, segundo dados da Febraban (2008), o processo de concentração dos bancos aumenta, especialmente por meio de aquisições e fusões com bancos estrangeiros. Tais aquisições têm um impacto direto no quadro de funcionários, reduzindo-o por meio de cortes de determinados cargos e acúmulo de funções para alguns funcionários, de modo a permitir as demissões de outros.

As rotinas bancárias foram terceirizadas ou normatizadas a partir do forte investimento em tecnologia da informação. Os conhecimentos técnicos dos trabalhadores bancários, por sua vez, foram sistematizados em manuais de trabalho. As antigas rotinas burocráticas cederam espaço para novas rotinas, especificamente aquelas ligadas à venda, à sedução e à manutenção dos clientes (Netz, 2005).

O aumento do número de contas correntes e, portanto, de clientes conduziu também a que os bancos aumentassem os produtos oferecidos. Essa ampla gama de produtos apresenta suas especificidades, as quais requerem muita atenção. Para os trabalhadores bancários isso representa uma mobilização subjetiva intensa, uma vez que suas metas mensais e até mesmo a manutenção de seus empregos dependem da venda desses produtos. Dependendo da faixa de renda dos clientes, os produtos oferecidos variam, bem como a complexidade do atendimento personalizado.

Os produtos oferecidos demandam também que os executivos dos bancos passem por muitos treinamentos corporativos, que são responsáveis por mantê-los atentos tanto às novidades do mercado quanto competentes em relação a todas as especificidades dos produtos. Os treinamentos, conforme mostra o site da Febraban (20I0), ocorrem geralmente fora do expediente de trabalho. Em geral, estão associados à mobilização subjetiva do executivo e à sua capacidade intelectual e afetiva, pois devem resultar em produtos intangíveis nos próprios executivos, tais como sentimentos de confiança, segurança e conforto, a serem transmitidos e identificados pelos consumidores. 
Assim, em geral, esses treinamentos associam-se à noção de trabalho imaterial. Para a construção de sua carreira, os executivos bancários dependem da realização destes. Deverá haver um sincronismo entre os treinamentos oferecidos pelo banco e a carreira almejada pelo bancário. São mais de vinte cursos oferecidos, com carga horária em média de vinte horas, que ilustram em seus conteúdos as demandas para a construção das carreiras dos executivos bancários associados aos altos resultados e desempenhos exigidos pelos diversos bancos (Febraban, 20I0).

A qualificação acompanha o ritmo acelerado das mudanças no setor. A valorização do saber, do conhecimento e das novas habilidades e atitudes compõe o novo trabalhador bancário. Assim como os próprios bancos estão se renovando, valorizam um contínuo processo de qualificação e de renovação de seus trabalhadores, independentemente do cargo que ocupam ou da idade. Entre os executivos, isso se evidencia com mais força, uma vez que, entre suas funções, está a de estrategista e planejador de todas as metas do banco, o que os coloca em posição de maior responsabilidade.

Os bancos nos quais se inserem as famílias dos executivos ilustram, portanto, o que vem acontecendo no setor. Alguns bancos que empregam os executivos sofreram processos de aquisição, cujo primeiro impacto foi o acúmulo de funções para esses funcionários. Com o aumento de atividades e o empenho e dedicação para realizá-las, vieram também as promoções, que possibilitaram tanto a construção da carreira quanto os aumentos salariais significativos. Tal construção teve repercussões diretas nas suas famílias, como se verá mais adiante.

\section{CARREIRA E DILEMAS}

Carreira profissional, aqui compreendida como sequência de experiências de trabalho das pessoas ao longo do tempo (Arthur, Hall, \& Lawrence, I989), tem sido objeto de interesse tanto no ambiente acadêmico como na mídia popular de negócios. Na esfera acadêmica, a carreira tem sido estudada principalmente pela interface com os seguintes temas: autogestão, comprometimento e desempenho, aprendizagem, gênero, expatriação, tal como indica uma revisão dos artigos relacionados à carreira em anais do Encontro Nacional dos Programas de Pós-Graduação em Administração (Enanpad), do Encontro Nacional de Gestão de Pessoas e Relações de Trabalho (ENGPR) e em três dos principais periódicos nacionais da área: Revista de Administração de Empresas (RAE), Revista de Administração da USP (Rausp) e Revista de Administração Contemporânea (RAC). Tal revisão abordou um período de cincos anos, entre 2004 e 2009. A palavra-chave para a procura dos artigos era "carreira". 
A mesma ênfase é dada pela mídia popular de negócios, sendo muito comum a oferta de "dicas" sobre a condução da carreira. Assim, constatou-se em revisão de artigos das revistas Você S.A. e Exame que a tônica das reportagens recai em orientações acerca do planejamento necessário para progredir profissionalmente e nas decisões supostamente acertadas para atingir o "sucesso profissional". Os mais diversos artigos das revistas mencionadas indicam atitudes, posturas e comportamentos necessários para a construção de uma imagem necessariamente positiva. Também sinalizam que investimentos e escolhas devem ser feitos em termos de formação e relações sociais, abrindo caminho para o percurso profissional ascendente, que não comporta a ideia de fracasso.

As indicações sobre carreira focalizam tão somente o indivíduo em sua esfera de trabalho, sem, por vezes, considerar que o contexto que o cerca pode tanto promover como restringir as possibilidades de ascensão. Para dar conta desse contexto, várias reportagens, por exemplo, as matérias "Sua carreira em 2009" (Você S.A., jan. 2009), "56 atitudes infalíveis para fortalecer sua carreira" (Você S.A., fev. 2009), "Seja o talento que o mercado procura” (Você S.A., jun. 2008), "Coragem para mudar" (Exame, dez. 2008), "Mundo sem fronteiras" (Exame, jul. 2008), "Executivos de sucesso" (Exame, out. 2008) apresentam "dicas" para o planejamento das trajetórias profissionais que sofreram impactos da atual crise do sistema financeiro. Também é ofertado pela mídia popular de negócio um modelo de inserção profissional e, particularmente, de construção de carreira, representado por carreiras bem-sucedidas, ilustradas com casos de profissionais em sua maioria jovens (até quarenta anos), muito bem remunerados.

Nota-se, assim, que tanto na esfera acadêmica quanto nas revistas populares de negócio as repercussões na vida pessoal produzidas pelo atual modelo de carreira não se mostram suficientemente problematizadas. Raras perspectivas críticas incluem em suas análises alguns condicionantes externos que repercutem na carreira dos sujeitos, como a necessidade de conciliar a vida profissional e a familiar, além da perda da referência do país de origem quando os executivos são expatriados, indicando a existência de dificuldades. Contudo, não aprofundam a discussão a respeito da sobrecarga acarretada pela responsabilização única dos sujeitos por suas carreiras, bem como não fazem referência aos possíveis dilemas que os profissionais vivenciam e às suas repercussões nas relações familiares.

Da mesma forma, em uma revisão em periódicos internacionais, tais como Human Resource Managment Review, Career Development International, Journal of Organizational Behavior, Journal of Vocational Behavior, Journal of Career Development e Gender, Work and Organization, nos quais o tema carreira é tratado de forma mais frequente, encontraram-se algumas indicações de que a carreira produz alguns dilemas, especialmente para as mulheres, como indicam os estudos de Mainiero e Sullivan (2005) sobre as carreiras caleidoscópicas que reportam os 
dilemas vivenciados por elas, especialmente em face da maternidade; as estratégias para encontrar o equilíbrio entre vida profissional e vida pessoal (Guillaume \& Pochic, 2007); os dilemas vivenciados por homens e mulheres nas decisões que envolvem as mudanças de cidade e, por consequência, resultam em negociações entre o casal: quem será o eleito para seguir a carreira? Em qual delas investir, do marido ou da esposa? (Sullivan \& Arthur, 2006).

Entretanto, nenhuma das publicações encontradas trata da especificidade dos dilemas pessoais relativos à carreira e suas repercussões nas relações familiares de modo a contemplar também o olhar daqueles que compõem as relações familiares. Pelo contrário, percebeu-se um número crescente de artigos com uma repetição das temáticas relativas à carreira, quais sejam: gênero, expatriação, competências gerenciais, comprometimento, empregabilidade e autogestão, especialmente nos periódicos nacionais, conforme aponta o estudo de Vazquez, Oltramari, Tonon e Garay (2010).

Dos dilemas relativos à carreira de executivos bancários e a percepção da família sobre eles decorrem também as consequências que nem sempre deixam marcas boas nos sujeitos que passam por essas escolhas visto que, na percepção de Bauman (2007a, p. 33), “quer seja livre ou não a escolha, o preceito de escolher livremente e de definir todas as ações como resultados desta não é, com toda a certeza, uma questão individual". A livre escolha, portanto, estaria fora do alcance, tanto para os executivos como para as famílias.

\section{DILEMAS CONTEMPORÂNEOS RELATIVOS À CARREIRA NOS ESTUDOS DA ADMINISTRAÇÃO}

Alguns estudos sobre temas relativos à problemática da carreira e os dilemas vivenciados por executivos concentram-se na insatisfação em relação ao desequilíbrio entre a vida pessoal e profissional e na denúncia de sofrimentos decorrentes do estresse gerado pela sobrecarga de responsabilidades (Scanfone, Carvalho Neto, \& Tanure, 2007; Tanure, Carvalho Neto, \& Andrade, 2006, 2007).

O desenvolvimento da carreira e as pressões no trabalho estão intimamente ligados, conforme demonstra o estudo de Costa e Honório (2009). O alto grau de cobrança, a disponibilidade para o atendimento das pessoas, a obsessão e compulsão por resultados são fatores que dizem respeito ao desenvolvimento das carreiras dos gerentes entrevistados nesta pesquisa e têm gerado forte estresse ocupacional. A quantidade de horas trabalhadas tem redundado no elevado consumo de bebidas alcoólicas e na piora da qualidade de vida pessoal. 
A piora da qualidade de vida também foi observada nos estudos de Santos, Siqueira e Mendes (2009), os quais analisam a vida de uma gerente lotada em um grande banco privado que buscou por tratamento psicológico após trinta anos de banco e estava afastada de suas funções no momento da pesquisa. $\mathrm{O}$ afastamento, segundo a pesquisa, justificava-se pelo excesso de trabalho, de modo que sua vida passara a gravitar somente em torno dos objetivos da empresa. O estudo evidenciou que as recompensas oferecidas pelo banco nunca foram proporcionais às intermináveis cobranças para o cumprimento das metas.

As pressões advindas da família são sentidas pelos executivos, homens e mulheres. Em particular, as mulheres sofrem com a pressão da família e as pressões do relógio biológico, determinadas pelas diferentes fases de sua vida, conforme estudos de Tanure et al. (2006). Os autores apresentam os desafios e os preconceitos em relação às escolhas enfrentados pelas executivas que chegaram ao topo da carreira. Neste estudo, mesmo insatisfeitas com o desequilíbrio entre vida pessoal e profissional, as mulheres se sentem realizadas com suas carreiras.

Outros estudos sobre dilemas relativos à especificidade do trabalho gerencial e às relações com a família encontram-se na coletânea feita por Davel e Melo (2005). Entre esses se destacam o estudo de Chanlat (2005), sobre o estresse, e o de Tremblay (2005), sobre a conciliação entre trabalho e família. O estudo de Tremblay (2005), em especial, sugere medidas advindas da empresa para o equilíbrio entre trabalho e família. Entretanto, aponta baixa implementação de tais medidas, apesar dos discursos dos gestores de recursos humanos e líderes sindicais preocupados com a questão.

Nessa mesma direção, Mainiero e Sullivan (2005) recomendam algumas ações para a retenção das mulheres nas organizações diante das dificuldades e dos dilemas em aliar trabalho e vida pessoal, a saber: horários flexíveis de trabalho aliados ao uso da tecnologia, interrupções na carreira de modo a reciclar-se, pacote de benefícios extensivos à família e incentivos financeiros para permanecerem trabalhando em casa.

Segundo Tremblay (2005, p. 87),

[...] os pais que trabalham se veem frequentemente obrigados a renunciar as oportunidades de promoção quando estas envolvem mudanças de horários ou maior responsabilidade profissional, mais tarefas ou jornadas de trabalho mais extensas, que ameacem o equilíbrio já frágil existente entre suas obrigações profissionais e familiares. 
É importante salientar que seu estudo diz respeito à realidade canadense, não à realidade brasileira, com suas peculiaridades, a saber: intensa flexibilização dos direitos trabalhistas, forte competição entre empresas e entre trabalhadores, entre outras.

O estudo de Tremblay (2005) merece atenção especialmente quanto ao uso do horário flexível do trabalho. Enquanto as mulheres utilizam o horário flexível para as tarefas domésticas, entre as quais cuidar dos filhos, os homens raramente o utilizam para as atividades ligadas à família, empregando o tempo para atividades pessoais, nas palavras da autora. Notam-se, desse modo, algumas diferenças no que tange à utilização do tempo fora do espaço de trabalho por homens e mulheres. Alguns estudos demonstram que as mulheres são as que mais sentem a pressão da família (Tanure et al., 2006), e esta diferença pode transparecer na intensidade dos dilemas pessoais vivenciados pelo universo feminino.

Esses dilemas também são vivenciados pelas mulheres entrevistadas na pesquisa de Veloso, Dutra, Fischer, Pimentel e Silva (2009), a qual constatou que as mulheres que apresentam mais tempo de trabalho na mesma empresa percebem negativamente a possibilidade de crescimento profissional, ao contrário dos homens, casados e com filhos.

Enquanto Tremblay (2005) apresenta a realidade canadense em que o trabalho ainda não se sobrepõe totalmente à família, o estudo de Tanure et al. (2007) revela que, atualmente, os executivos brasileiros estão chegando mais rapidamente ao topo da carreira em virtude das renúncias em relação à convivência familiar. Em seus estudos, vê-se que as tensões, o aumento das responsabilidades e a sobrecarga de trabalho interferem diretamente no convívio familiar. A ausência do executivo no cotidiano familiar resulta em sentimento de culpa. Ainda que se afirmem insatisfeitos em relação à falta de tempo para se dedicar à família, concluem que pouco podem alterar nessa situação, uma vez que a conquista do sucesso e do status os mantém reféns da carreira. Os executivos relataram também a luta para atingir o perfil requerido, o qual supõe estar bem também fora do trabalho, o que inclui ter uma família estruturada, apresentar-se de modo elegante e manter e estender suas relações sociais.

\section{CARREIRA E FAMÍLIA NA SOCIEDAdE LÍQUIDO-MODERNA}

Na sociedade líquido-moderna, dificilmente se sacrifica a satisfação individual em nome do bem-estar de um grupo, e a falta de incentivos às ações solidárias (Bauman, 2007b) promove tênues laços coletivos de defesa (Dejours, 2004). No trabalho, a exclusão de colegas, por exemplo, é uma prática comum no mercado, o que, de certa forma, também anuncia outras exclusões vindouras. 
Na vida líquida da sociedade líquido-moderna, a satisfação individual tende a ser passageira; assim, permite que os projetos de vida sejam de curto prazo e independentes de outras pessoas, possibilitando mais mobilidade para o sujeito (Bauman, 2004). Dessa forma, abandonar compromissos e lealdades, mesmo com arrependimentos, favorece a prontidão para mudar de tática e de estilo, por necessidade, prioridade e/ou incentivo.

Com tanta promessa de satisfação imediata e possibilidade de desejos ilimitados (Bauman, 2004, 2007a, 2007b), surge a dificuldade de lidar com a frustração. Aliás, não se tolera a frustração nem o alcance definitivo dos desejos, uma vez que a sensação de "quero mais" está sempre presente e é valorizada, além de ser naturalizada nos discursos atuais sobre a construção de carreira (Arthur \& Rousseau, 200I; Baruch, 2004a, 2004b; Briscoe, Hall, \& Demuth, 2006; Briscoe \& Hall, 2006; Sullivan \& Arthur, 2006).

Como recusar uma promoção diante do prestígio social que ela pode trazer? Guattari e Rolnik (2005, p. 48) sintetizam bem aquilo que alguns indivíduos vivenciam, afirmando que eles

[...] são reduzidos a nada mais do que engrenagens concentradas sobre o valor dos seus atos [...] são espécies de robôs, solitários e angustiados, absorvendo cada vez mais as drogas que o poder lhes proporciona, deixando-se fascinar cada vez mais pela promoção.

Quando os executivos vivenciam dilemas relativos à carreira, são, essencialmente, segundo Mansano (2003), guiados a preencher expectativas sociais. Neste caso, são expectativas da empresa pelo seu crescimento e da família também. No caso da família, como diz Bauman (2007a), é muito difícil para ela recusar o status e o recurso financeiro que uma promoção traz a todo o núcleo familiar. A consequência disso pode ser a não percepção de que seus atos podem repercutir mal nos relacionamentos pessoais e profissionais.

Os medos em relação ao futuro da família e ao futuro do profissional antecedem os dilemas. Vários medos são apresentados por Bauman (2007b). O medo da derrota potencializa os dilemas, especialmente em ambientes onde há "pessoas excedentes", tal como refere Bauman (2007b, p. 36). Entre os medos que antecedem os dilemas encontram-se o de ficar só, de sofrer, da fragilidade do corpo no trabalho, de ter limites para as promoções e para a carreira, de não alcançar a segurança total desejada na profissão almejada, da vulnerabilidade diante das escolhas profissionais, das incertezas da carreira que não podem ser suavizadas, do sentimento de impotência e da derrota diante das oportunidades de ascensão na carreira. 
O medo de ocupar a posição de "refugo humano" (Bauman, 2007a) encontra-se associado às decisões relativas aos dilemas pessoais. Bauman (2003, pp. 8-Io) diz:

Você quer segurança? Abra mão de sua liberdade, ou pelo menos de boa parte dela. Você quer poder confiar? Não confie em ninguém de fora da comunidade. Você quer entendimento mútuo? Não fale com estranhos. Você quer a sensação de aconchego do lar? Ponha alarmes em sua porta e câmeras de tevê no acesso.

É nesse sentido que se apresentam os dilemas pessoais no trabalho, uma vez que abrir mão ou conduzir mal a carreira é também correr o risco de ser descartado, refugado. Ainda, como refere Bauman (2007a, p. II), "participar do jogo não é uma escolha, mas eles [os trabalhadores] também não têm a opção de ficar de fora".

Associa-se à escolha relativa aos dilemas o poder gerencialista (Gaulejac, 2007) como forma de subjetivação ou de produção de modos de existência ou de estilos de vida. Para o autor, o poder gerencialista é um sistema de organização manifesta que se constitui em uma ideologia traduzida nas atividades humanas por indicadores claros de desempenho. O poder gerencialista constrói uma representação do capital humano como um recurso a serviço da empresa. Tal apropriação do indivíduo pela empresa produz subjetividades, que dizem respeito à glorificação da autonomia no trabalho, traduzida por empreendedorismo ou agentes de sua própria vida; à obsessão por metas e à rentabilização do corpo, entre outras. É nessa perspectiva que se encontram os executivos bancários.

$O$ poder gerencialista atua fortemente em relação à categoria tempo. Gaulejac (2007, p. 79) afirma que "o gestionário não suporta férias. É preciso que o tempo seja útil, produtivo e, portanto, ocupado. A desocupação lhe é insuportável [...] E a ausência de progresso para eles significa estagnação". Essas constatações do autor associam-se às ideias de Virilio (1996) sobre a ditadura da velocidade, que se acentua e potencializa por meio do vetor tecnológico, que recai sobre as mais diversas situações do trabalho e da vida em geral, e ilustra outros modos de privação e convívio familiar.

Bauman (2007b, p. 73) enfatiza: "A desintegração da solidariedade significou o fim da maneira sólido-moderna de administrar o medo". Os sujeitos, na sociedade líquido-moderna, administram o medo sozinhos ou contam com tênues vínculos afetivos, o que torna ainda mais difícil o enfrentamento dos dilemas. As famílias, por sua vez, distanciadas pelas contingências do trabalho, reforçam o desejo pelos resultados positivos que a carreira pode trazer, monetários ou em forma de status social. Observa-se a resignação em aceitar o cansaço, a ausência e a inversão da ordem das prioridades em que o trabalho e/ou carreira ocupa o primeiro lugar. Os trabalhadores não suportam o rótulo de excluídos, 
rejeitados, desempregados, e os sintomas dessa dor estendem-se à família por sua resignação.

Gaulejac (2007) refere-se às mudanças nas estruturas familiares decorrentes dos modos individualizados de trabalhar. Diz ele que, pouco a pouco, o espaço privado é invadido pela atividade gerencial, o que Guattari e Rolnik (2005, p. 32) compreendem como a colonização da privacidade do tempo livre. As novas tecnologias permitem, por exemplo, que os escritórios se instalem nos domicílios, ou onde quer que o sujeito vá. O que resta de "tempo livre é progressivamente dominado por preocupações de rentabilidade e de intensidade" (Gaulejac, 2007, p. ı80), que são também sentidas e vivenciadas pelos membros da família.

Todos na família são levados a viver em função dessa ideologia produtiva, já que

[...] contra o risco de tempo morto ou, pior, de desocupação, convém tornar produtivo cada momento. Nos seus mais jovens anos, a criança é preparada para tornar seu tempo rentável: curso de música, atividades esportivas, cursos particulares, recreações formativas e distrações instrutivas (Gaulejac, 2007, p. I80).

Fora isso, "há uma variedade de aparelhos de alta tecnologia invadindo o cotidiano familiar" (Ferreira Neto, 2000, p. I09), tais como os notebooks, aparelhos celulares, palm-tops, entre outros que a ciência está para inventar.

Nesse sentido, pelo estudo de Mansano (2003), pode-se dizer que os dilemas vinculados à profissionalização já estão postos antes mesmo do início das trajetórias da carreira. O indivíduo, ainda jovem, enfrenta o dilema no momento da escolha de uma profissão. Essas escolhas, segundo a autora, são orientadas e limitadas pelo mercado de trabalho e buscam preencher as expectativas sociais, que, em última análise, constituem-se em estratégias de poder para controlar a inserção do indivíduo.

A carreira se vê associada aos ditames do mundo do consumo, uma vez que este se apresenta com infinitas possibilidades de escolha, nem sempre favoráveis aos indivíduos. Entre escolher permanecer mais tempo com a família ou progredir na carreira, alguns escolhem a carreira, já que se mostra mais desafiante e fascinante: "filhos versus carreira e confinamento doméstico versus um mundo de contínua aventura; o tédio dos filhos versus os espaços jamais totalmente explorados e, portanto, eternamente fascinantes do 'lá fora'" (Bauman, 2007a, p. I35).

Sobre a difícil conciliação entre consumo, trabalho e filhos, encontram-se ainda em Bauman (2007a) algumas considerações. O autor afirma ser assustador para alguns casais da sociedade líquido-moderna a possibilidade de vida na qual é necessário contar cada centavo. Seria esta a noção vigente a respeito de filhos na 
atualidade. Os filhos representariam não somente uma vida entediada, que distancia os executivos das possibilidades de "aventuras" patrocinadas pelo mundo corporativo, mas, sobretudo, uma fonte de custos incalculável. Alguns casais admitem uma sensação de ressentimento em relação ao estilo de vida e à riqueza material dos amigos que, sem filhos, têm tempo e dinheiro para atividades sociais e viagens. Os vínculos com poucas responsabilidades ficariam isentos de regras e mostrar-se-iam perfeitos para a sociedade líquido-moderna da "soberania do consumidor". "Não se pode ter as coisas a não ser comprando-as, e comprá-las significa que outras necessidades e desejos terão de esperar" (Bauman, 2007a, p. 136). Na sociedade líquido-moderna, comprar e satisfazer os desejos do consumismo é mais importante que as responsabilidades com esposas ou maridos ou com filhos.

\section{MÉTOdO DE PESQUISA}

Apresenta-se neste item o método de pesquisa utilizado. Para tanto, há a descrição e o modo de acesso aos participantes, a coleta e a forma de análise das informações. Destaca-se novamente o objetivo do artigo, que consiste em analisar como aqueles que compõem as relações familiares de executivos bancários percebem como estes enfrentam seus dilemas pessoais relativos à carreira, bem como analisar que estilos de vida resultam da condução da carreira de executivos bancários em contexto de trabalho imaterial.

\section{1 PARTICIPANTES DA PESQUISA}

Os sujeitos participantes da presente pesquisa são aqueles que compõem as relações familiares de executivos bancários. Eles foram acessados a partir das indicações dos próprios executivos, que foram entrevistados para responder a outro objetivo de pesquisa; suas falas não serão relatadas nem analisadas neste artigo. Buscou-se ampliar a fala dos executivos com os representantes de suas relações familiares devido à compreensão de que o dilema imputado a eles não resulta tão somente seu, mas envolve também os relacionamentos familiares. Os executivos, portanto, sugeriram os familiares cujas falas serão apresentadas no artigo, para a entrevista. Os familiares foram entrevistados entre os meses de junho de 2008 a outubro de 2009 . Participaram da pesquisa ao todo quatorze representantes das relações familiares dos executivos bancários. O número de entrevistados foi determinado pela acessibilidade, já que o agendamento das entrevistas geralmente se dava com três a quatro semanas de antecedência. Geralmente, os membros das relações familiares eram ocupados com as atividades domésticas, além de seus trabalhos e estudos. 
Dos quatorze representantes entrevistados, sete eram esposas, dois esposos, duas filhas, uma amiga ${ }^{\mathrm{I}}$, um filho e uma irmã. As entrevistas com os representantes das relações familiares foram realizadas em suas casas ou em estabelecimentos comerciais, como cafés ou bares em Porto Alegre, conforme sua opção. O Quadro I apresenta a caracterização dos participantes.

\section{QUADRO I}

CARACTERIZAÇÃO DOS PARTICIPANTES DA PESQUISA

\begin{tabular}{ccc}
\hline FAMILIAR & REPRESENTAÇÃO NA FAMÍLIA & IDADE \\
\hline A & Esposa & 45 \\
\hline B & Esposa & 50 \\
\hline C & Esposa & 25 \\
\hline D & Filha & 20 \\
\hline E & Esposa & 44 \\
\hline F & Filho & 23 \\
\hline G & Esposa & 44 \\
\hline$H$ & Filha & 28 \\
\hline I & Esposa & 40 \\
\hline E & Esposa & 36 \\
\hline$K$ & Amiga & 34 \\
\hline$L$ & Esposo & 38 \\
\hline$M$ & Esposo & 27 \\
\hline$N$ & Irmã & 30 \\
\hline
\end{tabular}

Fonte: Elaborado pelas autoras.

\subsection{ACESSO AOS SUJEITOS E COLETA DE INFORMAÇÕES}

Conforme já anunciado, os contatos com os sujeitos da presente pesquisa deram-se por meio dos executivos bancários. Para a coleta de dados propriamente dita considerou-se, então, a técnica da entrevista individual ou em profundidade.

A entrevista individual foi utilizada em razão de que "assuntos de sensibilidade particular podem provocar ansiedade” (Gaskell, 2003, p. 78), tal como se imaginou que poderia ocorrer em relação à questão dos dilemas pessoais no que diz respeito à carreira, o que realmente aconteceu.

A técnica de entrevista mostrou-se importante para a pesquisa ao mapear "a compreensão dos mundos da vida dos entrevistados e de grupos sociais especificados" (Gaskell, 2003, p. 65). Cabe lembrar que se observou que as "falas ou

1 No caso de uma executiva que não havia constituído família e seus irmãos moravam em São Paulo, ela indicou uma amiga/colega de banco para a entrevista. 
comentários que numa primeira escuta pareciam sem sentido, podem, repentinamente, entrar em cena à medida que as contribuições de diferentes entrevistados são comparadas e contrastadas", exatamente como pondera Gaskell (2003, p. 7I).

As entrevistas tiveram duração aproximada de 60 minutos, e tomaram por base um roteiro destinado aos familiares com um total de $\mathrm{i} 8$ questões. $\mathrm{O}$ roteiro possibilitou melhor exploração das categorias em estudo sob o ponto de vista dos familiares. Além disso, é importante mencionar que mesmo se tratando de um roteiro, as entrevistas foram flexíveis de modo a contemplar o sentido das falas dos entrevistados.

A entrevista contemplava os aspectos: cotidiano familiar; percepção do familiar sobre a construção da carreira do executivo; participação da família no percurso profissional do executivo.

A realização das entrevistas propiciou não apenas o acesso a informações. As entrevistas constituíram momentos de reflexão e, não raro, propiciaram manifestação de emoções. Cabe registrar que, em geral, as entrevistas com os membros das relações familiares dos executivos se mostraram momentos de emoção nem sempre contida. Silêncios, engasgos, titubeios e lágrimas se evidenciaram. As emoções despertaram respeito ao sofrimento alheio por parte das entrevistadoras que constataram, de imediato, tratar-se de um tema mobilizador para os entrevistados e também para si, ante o sentimento cristalino expresso por meio das palavras e dos gestos corporais. Tal fato aponta para a existência de uma demanda de escuta e reflexão que parece não encontrar espaço nem tempo no cotidiano de trabalho.

\subsection{ANÁLISE DOS DADOS}

A análise dos dados iniciou-se já no momento mesmo da entrevista, a partir da escuta da fala dos entrevistados que, de alguma maneira, propiciou uma compreensão panorâmica da realidade que se delineava.

A análise da fala dos entrevistados seguiu as orientações propostas por Minayo (200I). Desse modo, as entrevistas constituíram um processo com três momentos essenciais e mutuamente enriquecedores: a entrevista presencial, a escuta da gravação e a leitura da transcrição. Este último momento foi importante, pois, “ao ler as transcrições, são relembrados aspectos da entrevista que vão além das palavras e o pesquisador quase que revive a entrevista" (Gaskell, 2003, p. 85). As entrevistas foram lidas tantas vezes pelas pesquisadoras que no momento da análise dos dados várias frases vinham à memória com muita facilidade.

As informações obtidas nas entrevistas foram agrupadas a partir das análises propostas: carreira no trabalho imaterial bancário e suas repercussões nas relações familiares; privação da convivência; apropriação e desapropriação do tempo 
de vida em geral; mal-estar provocado pela hipersolicitação; reprodução acrítica do modelo vigente para o futuro dos filhos. Cabe ressaltar que os resultados serão apresentados com base nessas categorias. Nesta etapa de sistematização das informações, estas foram lidas, relidas e exploradas. Para a visão ampliada do conjunto de informações, elaborou-se um mapeamento dos registros obtidos. A transcrição das falas se encontra na linguagem oral dispensando-se, portanto, o uso do "[sic]" na indicação delas. O material produzido nesta fase foi analisado e interpretado com base no referencial teórico adotado, buscando compreender como aqueles que compõem as relações familiares de executivos bancários percebem como estes enfrentam os seus dilemas pessoais relativos à carreira. No intuito de manter o sigilo sobre as respostas, os informantes foram denominados: A, B, C e assim sucessivamente.

\section{RESULTADOS}

\subsection{CARREIRA NO TRABALHO IMATERIAL BANCÁRIO E SUAS REPERCUSSÕES NAS RELAÇÕES FAMILIARES}

Em geral os executivos reproduzem, de modo acrítico, o discurso organizacional que lhes impõe um estilo de vida do qual se tornam reféns. Tal discurso não atinge tão somente o indivíduo, mas também aqueles de suas relações afetivas, de amizade ou familiares. É desse modo que, ao ver o seu estilo de vida reforçado aos olhos dos outros, o executivo responde sim às demandas de aceleração do ritmo, ou ao desenraizamento contido na mobilidade espacial. Uma das esposas entrevistadas (B) diz: "eu acho que, se tu quiseres fazer uma boa carreira, precisa uma boa dose de sacrifício, sem ele ninguém chega a lugar algum".

A filha $(\mathrm{H})$ de um executivo declarou que seu pai sempre colocou a sua carreira como prioridade na vida dele e da família também. $\mathrm{H}$ fala:

Meu pai sempre foi dedicado à empresa e sempre procurou buscar mais, o banco virou a prioridade na vida dele. Todas as oportunidades que ele teve não deixou passar. Em todas as mudanças nossa família sempre acompanhou, especialmente meu irmão mais novo e minha mãe.

O trabalho e a carreira tornam-se uma obsessão, sendo muitas vezes a distração sentida como uma perturbação. Entre as perturbações, insere-se a família (Gaulejac, 2007). Uma esposa (C), cujos planos após se casar contemplavam ter filhos, diz que essa decisão teve de ser adiada. 
Eu dizia que quando eu me formasse, eu queria ter um filho. Aí agora estou de carteira assinada, acabei minha faculdade e o filho nem pensar porque não tem condições, como é que eu vou ter um filho? Ele [esposo] vai enlouquecer. E ele mesmo não quer isso. Porque eu vou sofrer, ele vai sofrer com certeza. Seria ser uma mãe sozinha porque pai vai ter pouco.

Entretanto, ainda que a percepção de ambos seja convergente, não produz um movimento para agirem de outra forma, optando por limitar o trabalho ao ponto que possibilite mais tempo em família. Sendo próprio do dilema, esta nova opção também demandaria perdas. Como afirma Bauman (2009), mudar de direção está fora de questão e recuar é simplesmente impensável.

O dilema é vivido como exigência de posicionamento pessoal, mas a repercussão do posicionamento é coletiva. Uma das esposas (G) relatou: "após um mês da primeira mudança de cidade, sua filha nasceu e ela teve depressão pós-parto. Então seu marido seguidamente lhe dizia: 'Parece que tu não ficaste feliz com nossa mudança'”. Dessa época, lembrou que as decisões relativas à profissão tiveram repercussões ruins na família, especialmente porque era o início tanto da carreira como da constituição da unidade familiar. Cabe ressaltar que esse modo de trabalhar e viver afeta a saúde também dos filhos dos executivos bancários, levando-os, às vezes, ao uso contínuo de medicamentos. Um dos filhos entrevistados contou com naturalidade que não tem se sentido bem: "Hoje já tomei um dorflex e minha fluoxetina [antidepressivo]" (D).

Conforme observa Dejours (2004), o sofrimento tem sido vivido em solidão. No relacionamento familiar todos são atingidos, mas nem todos conseguem compartilhar.

A esposa confirma: "é só o banco, banco, banco" (C). Ela diz que o trabalho do seu marido consome inclusive os finais de semana. Essa é uma prática comum entre todos os executivos.

A carreira define-se, portanto, também a partir da mobilidade forçada. A filha (H) desse executivo constatou o seguinte, em uma das mais difíceis entrevistas realizadas, pela emoção que veio à tona:

Eu convivi muito pouco com meu irmão mais novo. O pai sempre achava que ele tinha que aceitar todas as propostas. Então, eu e meu irmão nos separamos quando eu era adolescente e ele era criança. Nessa fase é que meu pai mudava muito de cidade, eu tinha i7 anos, e a partir daí eu nunca mais acompanhei o pai e a mãe $(\mathrm{H})$. 
Os filhos sentem a ausência dos pais e dos irmãos, uma ausência que, uma vez instalada, anuncia-se como jamais suprida.

Em outros casos, toda a família mudou-se acompanhando o novo percurso na carreira do executivo bancário, que, para alcançar um cargo de destaque, teve como pré-requisito as constantes mudanças de cidade.

A mobilidade espacial, em geral, envolve transtornos para a família, especialmente para os filhos, conforme descreveu uma das esposas (E):

Quando ele chegava em casa e contava que ia ter outra mudança, a gente ficava triste, mas tentava não decepcionar ele. A última promoção foi em questão de um dia. Ele já tinha que dar uma resposta, de um dia para o outro ele tinha que dizer: ou vou ou não vou. Então, ele, na verdade, já tinha decidido ir, só que daí o impacto na família foi muito grande... nosso filho mais novo foi se esconder embaixo da mesa e dizia: "Pai, eu não vou, não vou". O que fez ele se sentir muito culpado, porque ele fica se culpando de tirar as crianças, de mexer com a família.

O imperativo da velocidade que rege as relações de trabalho assola as relações familiares, definindo seu ritmo e destino de modo nem sempre desejado. Os dilemas relativos à mobilidade espacial e funcional estão sempre rondando as relações familiares dos executivos bancários. São difíceis de enfrentar porque fazem parte da mobilidade forçada que os bancos propõem aos executivos. As mobilidades espacial e funcional vividas no superlativo deixam a vida da família um caos. Uma esposa (A) confirma tal sentimento:

As decisões mais difíceis que eu considero foram as de mudança de uma cidade para outra e a gente tinha que tomar a decisão e não tem todo o tempo do mundo para decidir, tem um tempo X. Então essa insegurança foi difícil. O dilema maior de nossas vidas foram essas mudanças. Principalmente depois que tu tens filho, eu tinha que viajar para [nome da cidade], viemos para cá [nome da cidade] e mudou completamente. Esse tipo de decisão, saber se tu estás fazendo a coisa certa ou não, se tem que esperar mais um pouco, ou não tem, porque envolve a vida de todo mundo.

\subsection{A PRIVAÇÃO DA CONVIVẾNCIA}

As condições de manter a convivência familiar ao longo da carreira são escassas para toda a família. A filha de um dos executivos, em uma fala, emocionada, 
revela que pouco conviveu com a família. Em função das mudanças de cidade associada à troca de agências, ela optou por não acompanhar seus pais e seu irmão mais novo.

Nota-se que, para disponibilizar-se de tal modo ao trabalho, os executivos contam com aqueles que compõem suas relações familiares no sentido de legitimar a escolha e arrefecer a vivência do dilema relativo à privação da convivência. Uma das esposas sabe que, "quanto mais sobe, mais estressa, a gente passa sufoco, até porque ele fica muito longe da família" (I). Embora tenha consciência das incertezas, "a gente nunca sabe o dia de amanhã e isso dá medo" (I). A esposa propõe-se a manter o marido no processo de individuação, a favor do projeto organizacional e do estilo de vida condizente com o consumo na sociedade líquido-moderna. Para tanto, é afirmativa em relação ao futuro do esposo, que delineará também o seu estilo de vida. "O futuro do [nome executivo] é chegar lá no topo. E eu como esposa ajudo para isso. Já adquirimos com esse objetivo melhor oportunidade de compra, de consumo e da qualidade de vida" (I). Nas palavras de Bauman (2009, p. 35), "o consumo não leva à certeza e à saciedade. O bastante nunca bastará”. Para uma vida de consumo a opção pela carreira é compreendida como a melhor escolha e, para os executivos bancários mais jovens e aqueles de suas relações familiares, a família não está em questão.

As relações de coleguismo, por vezes, são vistas também pelas esposas como empecilhos ao objetivo de "chegar lá no topo" (I), o que intensifica a competição no aqui e agora em detrimento da manutenção de relacionamentos de coleguismo no futuro.

A dedicação ao trabalho dos executivos geralmente é inversamente proporcional aos conhecimentos que detêm a respeito da vida dos filhos. Isso ocorre também porque as esposas assumem o convívio com os filhos, liberando os maridos para o trabalho, o que se faz acompanhar de queixas: "Não posso contar com ele para nada, nem para cuidar das crianças, nem para uma reunião da escola, nem para as atividades domésticas" (E). Novamente, a naturalização das escolhas não satisfatórias feitas em nome da carreira chama a atenção. A esposa E, por exemplo, abriu mão de sua carreira profissional para cuidar da casa e dos filhos, liberando mais seu companheiro para as escolhas que não a contemplam. A rotina de trabalho e o estilo de vida dos executivos bancários provocam a ausência dos pais no contexto familiar e, consequentemente, a ausência de referência paterna e o sentimento de abandono dos filhos. As constantes viagens de um dos executivos bancários, associadas ao enigma que seu trabalho representa, geraram um sentimento assim expresso pela filha: "Meu pai nunca está em casa. Eu nunca o vejo e isso que eu moro com ele. Praticamente eu moro sozinha" (D). E ainda: "Eu não sei o que ele faz, sobre o trabalho do pai eu não converso com ele sobre isso. A gente não se encontra, ele vive viajando” (D). 
Os relacionamentos que se estabelecem entre os executivos bancários e seus filhos mostraram-se pelo distanciamento, pela falta de diálogo e pelos desentendimentos. Uma filha contou que

[o pai] mistura muito o trabalho dele com a casa, chegar mal-humorado interfere muito. É porque ele vive viajando. Teve uma semana que ele passou em Brasília, outra em Curitiba, vive em reunião. Não sei por que faz tanta reunião. Ele nunca parou para contar nem eu para perguntar (D).

Parar para contar ou para perguntar é uma barreira a ser imposta à velocidade que assola a vida atual, o que nem sempre é possível pela própria ausência do pai executivo ou mãe executiva.

Outra filha $(\mathrm{H})$ relata:

Acho que está na hora de ele parar, porque é muito estressante e ele não tem horário. A qualidade de vida dele é ruim, meu pai chega em casa onze horas da noite. Isso quando chega cedo. Ele não tem tempo para um lazer, nada disso. Toda vez que venho visitar ele, é sempre igual, não muda.

As palavras de outro filho $(\mathrm{F})$ revelaram mais outra queixa:

Essa última função dele [o pai] é onde eu vejo que ele mais se esforça e também fica mais cansado. É a função que mais dá trabalho, assim eu vejo. Eu vejo que ele nunca para em casa, está sempre em reunião, na corrida. Se a gente sai para almoçar aqui em Porto Alegre, o celular dele toca dez vezes enquanto nós estamos almoçando. Eu não entendo por que ele não desliga o celular, por que não tem um minuto de sossego. Mas ele não desliga.

Tais achados convergem com os da pesquisa de Tanure et al. (2007). Os autores constataram que as novas tecnologias, tais como computadores portáteis, telefones celulares, correio eletrônico, BlackBerry, entre outras inovações, não resultaram na redução da jornada de trabalho mas, sobretudo, no aumento do tempo de não trabalho. As tecnologias invadiram os espaços da vida privada: o lar, o lazer e a intimidade da família. Não há mais limites entre os espaços pessoal, de trabalho e social. Diante disso, impõe-se a questão: continuarão os executivos a disponibilizarem-se totalmente ao projeto organizacional no presente e acumular para o futuro memórias tristes em relação à privação da convivência com aqueles de suas relações familiares? 
O estresse e a possível falta de qualidade de vida não são suficientes propulsores do abandono da profissão, indicando que não só o trabalho atua como modo de subjetivação ou de produção de estilos de vida. O suporte para a construção, manutenção e progressão da/na carreira, via de regra, reside na família, em especial na figura das esposas, que não hesitam em restringir suas próprias carreiras em favor da de seus maridos. A esposa de um executivo (A) bancário exemplifica essa situação:

Eu acho que o que eu contribuí é que eu sempre estive disposta. Se nos mandassem hoje para Brasília e precisasse ir junto, eu nunca compliquei. Essa primeira vez que a gente foi para Santa Maria ele chegou em casa num dia e no outro nós já estávamos indo com a nossa mudança para lá. Então, eu nunca coloquei empecilho nenhum. Então, eu acho que eu colaborei mais nesse sentido, de ele poder mudar sem ter maiores problemas.

As esposas, em geral, foram mais condescendentes em relação à construção da carreira dos maridos executivos bancários do que o contrário. O dilema relativo à privação da convivência encontra acolhida entre aqueles que compõem as relações familiares dos executivos bancários no sentido de as escolhas, mesmo não sendo satisfatórias, favorecerem o projeto organizacional do prisma da construção, manutenção e progressão na/da carreira individual. A manutenção do estilo de vida, ou, como diz I, "melhor oportunidade de compra, de consumo", costuma ser apresentada como moeda de troca ou compensação diante da privação da convivência, o que aprisiona ainda mais o executivo bancário à carreira, num processo de individuação que produz as subjetividades necessárias ao trabalho imaterial.

\subsection{APROPRIAÇÃO E DESAPROPRIAÇÃO DO TEMPO DE VIDA EM GERAL}

De modo geral, quase todos os familiares disseram que os executivos utilizam o espaço da casa para o trabalho. A percepção de que o trabalho captura a vida é relatada por um marido de uma executiva. A ilusão acerca da existência de fronteiras espaçotemporais que delimitam o trabalho numa jornada não diz respeito ao executivo bancário nem a sua família, que tem claro que vida e trabalho se sobrepõem um a outro. O marido $(\mathrm{M})$ de uma executiva bancária comenta como a esposa rentabiliza seu tempo: "Se ela leva trabalho para casa? Sim, mesmo que não seja trabalhando com as mãos ela fica com a cabeça no mínimo seis a oito horas pensando, calculando, elaborando propostas e situações". 
Um esposo tem dificuldade para perceber que o trabalho imaterial associa-se às formas mais sutis de controle e de sedução ao projeto organizacional. Por meio de sua fala, entende-se que a otimização do tempo e da carreira é, além de monitorada pelo banco e pela própria executiva, também controlada pela família. Sua fala ilustra a percepção que tem da construção da carreira da esposa. L diz:

Eu sempre falo para minha esposa: "O bom profissional é aquele que executa o trabalho que lhe é passado, como se fosse o proprietário da empresa”. Por isso, o que colaborou para a carreira dela foi a dedicação diária, esforço mais do que ela mesmo imagina, concentração e determinação. Ela se mantém atualizada todo tempo, especialmente quando ela quer ser competitiva. Eu incentivo isso.

O controle que está na esfera do autodisciplinamento e na empresa reflete-se na família. A exemplo de L, alguns membros familiares incentivam tais formas de sujeição ao garantirem ao executivo que suas decisões a favor do projeto organizacional são importantes para ser um bom trabalhador e construir uma carreira de sucesso. A família inteira volta-se à perspectiva do crescimento e passa a ser de responsabilidade do executivo ou da executiva conquistá-lo. Em geral, os executivos não contribuem nas atividades domésticas, que ficam aos cuidados das esposas.

As novas configurações da carreira individual, quais sejam, as carreiras sem fronteiras e proteana (Arthur \& Rousseau, 200I; Baruch, 2006; Briscoe et al., 2006), possibilitaram também novas configurações familiares. A disponibilidade total ao banco a fim de ascender na carreira muda a estrutura e os relacionamentos familiares. Casais moram em casas separadas, mulheres não constituem família, homem jovem que opta por vida de solteiro e sem filhos a fim de ter mais tempo disponível para a construção da própria carreira.

As falas a seguir mostram que tanto os executivos como seus familiares sentem as diferenças nas configurações familiares: “A mãe nunca quis deixar o emprego dela. Então, ela nunca acompanhou o nosso pai nas mudanças. Eles moram já há um tempo separados” (F); “Eu acho que meu irmão conseguiu alcançar um cargo importante e consegue se dedicar I00\% para o trabalho porque ele não tem família. Ele optou por ficar solteiro, e isso facilita a vida profissional dele" $(\mathrm{N})$.

As possibilidades de transferir a carreira organizacional para a individual na perspectiva do gestor de si e, dessa forma, dar-lhe mobilidade para planejar sua vida pessoal e profissional a seu modo, tal como preconiza a carreira sem fronteiras, também abriu mais espaço para o trabalho e, consequentemente, para a ascensão na carreira, especialmente para os executivos bancários solteiros.

O envolvimento da família no trabalho do executivo corrobora com os dados de Rosenfield (2004) sobre a servidão voluntária, uma vez que tanto o executivo 
como a esposa trabalham nos finais de semana. Os ganhos de produtividade acontecem na intensificação do trabalho e, nesse caso, pela rentabilização do tempo da família também. Portanto, quem cobra a finalização do trabalho são os filhos ou a esposa, não mais a empresa, transferindo, desse modo, a responsabilidade do alcance dos resultados para a família. O espaço, que antes era da intimidade, privado à família, é agora também local de trabalho.

Os cônjuges entrevistados têm clara percepção da intromissão do trabalho na esfera doméstica:

Ele costumava ficar até mais tarde no banco, mas não levava trabalho para casa, ele nem acesso à internet tinha em casa. Agora tem que ter acesso nas 24 horas, dá para dizer... E tem o celular também, às vezes até durante o almoço toca, daí ele fala: "Crianças vocês vão lá para o quarto, o pai vai atender um cliente, daí vocês ficam quietinhos.” Então não tem horário, ele tem que atender... (G).

Outra esposa descreveu assim a rotina do marido:

Daí ele liga o notebook, faz as coisas que ele tem para terminar, isso depois da janta. Aí quando ele deita, imagina, lá pelas is horas da noite, ele vai ler alguma coisa. Ele não deita sem ler alguma coisa, livros (leituras de atualização profissional). Ele ainda tem esse tempinho antes de dormir para se atualizar (E).

Destaca-se na fala desta esposa que a leitura realizada atende à lógica de capacitação permanente e continuada para o trabalho, na busca da atualização e competência. Ainda, o trabalho é facilitado pelas próteses tecnológicas (Virilio, I996) que se representam aqui nos aparelhos celulares e notebooks. A busca dessa qualidade de atualização rentabiliza todos os momentos da vida, o que condiz com a noção do trabalho imaterial. Nos finais de semana e à noite, a realização do trabalho é possibilitada pela tecnologia, que indetermina a jornada de trabalho, conforme relata a esposa de um executivo: "Quando ele chega em casa, é ele e o notebook. Então, como é que vai parar para conversar? Então, tem que deixar” (C). $\mathrm{O}$ acesso às novas tecnologias permite instalar um escritório domiciliar, colonizando, assim, o espaço e o tempo pessoal, que antes eram utilizados para atividades de lazer com os filhos.

A busca pela atualização constante por meio de leituras e informações da internet se funde com o trabalho imaterial, que se efetiva pelos atendimentos ao telefone e a construção das estratégias de trabalho no banco. Essa busca é sentida com intensidade pelos membros das relações familiares, tal como expressa $\mathrm{H}$, filha de um executivo bancário: 
Meu pai não desliga do serviço, na verdade ele não traz para fazer em casa, quando ele chega o telefone não para de tocar, ele fica pensando nas coisas que tem que fazer, nas coisas do banco, nas metas que tem que atingir. Também fica preocupado em ler todos os jornais sobre o mercado financeiro e acessar à internet.

A condução da carreira associada à noção de trabalho imaterial e o enfrentamento de dilemas por parte dos executivos bancários resultam em estilos de vida que alcançam também aqueles de suas relações familiares.

\subsection{MAL-ESTAR PROVOCADO PELA HIPERSOLICITAÇÃO}

A mobilização total do indivíduo em prol do trabalho redunda "em sintomas de superatividade" (Gaulejac, 2007), fato que tem se desdobrado em adoecimentos também da família. Um das esposas disse que enquanto ela e o marido moravam separados, especialmente no início da transição do marido para outra cidade, "ficava sem dormir. Me dava pânico dormir sozinha. Daí passei a tomar antidepressivos" (C).

As mudanças nos estilos de vida se refletem nos cuidados com a saúde, que, de certo modo, são delegados às esposas. Nesse sentido, duas das esposas relataram: "Eu vou ao meu médico e peço para ele requisições para levar para meu marido fazer os exames. Mas ele não arruma tempo nem para fazer os exames” (B).

Eu marco a consulta e no dia eu ligo avisando [o marido executivo bancário], porque o que é fora do trabalho ele esquece. Mas eu também acho que ele não vai ao médico porque ele não quer perder tempo, ele se culpa por não estar trabalhando (E).

Outra esposa, por sua vez, relata que eles se dividem nas responsabilidades domésticas de modo a evitar que um ou outro assumam todas as tarefas da casa. Ela cuida da saúde das crianças, da escola e da casa. Ele paga as contas e cuida das finanças da família. Tal manifestação ilustra a forma como o casal partilha as responsabilidades e remete a que Holzmann (2006) classifica como trabalho produtivo e reprodutivo. Tal divisão sexual do trabalho faz referência ao sexo, sendo as atividades reprodutivas, como o trabalho doméstico, frequentemente associadas às mulheres, ao mesmo tempo que o trabalho produtivo, remunerado e valorizado socialmente é remetido aos homens.

Na lógica vigente produtiva, os executivos raramente conseguem ficar improdutivos. Um filho comenta sobre seu pai: 
Ele é muito ativo. Ele nunca para. Ele não chega em casa e deita no sofá para assistir TV. Ele chega em casa, dá uma deitada de uns vinte minutos e depois ele sempre vai fazer alguma coisa. Ou ele vai jogar tênis, ou ele vai jogar futebol, caminhar. Ele nunca fica em casa (F).

Uma esposa revela que "hoje se saímos para jantar, passear, ele diz que está perdendo tempo" (C).

Os turnos da manhã e da tarde não são suficientes para os executivos realizarem o trabalho, dizem as esposas. Isso redunda no uso do turno da noite para manterem-se atualizados, dizem elas. A hipersolicitação via atualização profissional recai na falta de convívio familiar à noite. Uma esposa diz: "ele não senta no sofá, tira o sapato, como se esperava que se fizesse ao chegar do trabalho. Ele fica até as 23 horas no notebook interligado ao sistema do banco terminando o que tem para fazer e preparando o dia seguinte" (E).

Embora essa seja a lógica vigente de relacionamento que é provocada pela hipersolicitação, uma das esposas entrevistadas disse que o casal ainda consegue manter alguma resistência no reduto familiar. Ela diz: "quando ele chega em casa, ele pede para não falar sobre trabalho” (A). Já outra menciona que falar sobre o trabalho é o único modo de elaborar a hipersolicitação e poder retornar ao trabalho no dia seguinte. Ela diz: "de noite temos que conversar sobre o trabalho dele para ele se acalmar" (I).

\subsection{REPRODUÇÃO ACRÍTICA DO MODELO VIGENTE PARA FUTURO DOS FILHOS}

Há uma reprodução acrítica do modelo vigente de condução da carreira e "da perspectiva” de sucesso no futuro dos filhos. Maridos e esposas tendem a gerenciar a agenda dos filhos, acionam conselhos para suas carreiras e, muitas vezes, decidem o futuro profissional deles.

O distanciamento da família é considerado necessário para que o executivo se mantenha provedor, mas também é considerado, em especial pelas esposas, como possibilidade de abrir portas ao futuro profissional de seus filhos, além de apresentarem-se modelo no qual eles devem se inspirar para seu futuro profissional. A educação dos filhos é perpassada pela mesma lógica pela qual os pais conduzem suas carreiras. Uma das esposas afirmou "ter que educar ele [filho] para competir" (B). Em geral, esse modelo é focado no sentido da repetição, pois querem também que seus filhos sejam os melhores no mercado de trabalho. Esse modelo de educação é partilhado por algumas esposas: 
Para nosso filho também é bom ver tudo isso, com certeza, porque naquela época, eu me sentia chateada... dizia para ele: “Olha, filho, teu pai está ausente, mas é para o futuro profissional dele. Não tem outra alternativa”. Eu dizia que o dia em que ele fosse trabalhar também ia ser por aí. E eu tentei criar nosso filho sempre nessa direção (B).

Além do modelo do pai, os filhos têm suas vidas preenchidas por uma agenda carregada de atividades que passam a serem investimentos no futuro profissional. Gaulejac (2007, p. I80) analisa as repercussões do excesso de atividades sobre as crianças e afirma:

[...] contra o risco de tempo morto ou, pior, de desocupação, convém tornar produtivo cada momento. Desde seus mais jovens anos, a criança é preparada para tornar seu tempo rentável: curso de música, atividades esportivas, cursos particulares, recreações formativas e distrações instrutivas.

O modo de controlar a produção escolar, menciona Gaulejac (2007), é um acompanhamento sistemático, com um diálogo confiante em que se examinam e se ponderam os pontos fortes e fracos dos filhos, fixando objetivos e etapas de progressão, aplicando a lógica da gestão de recursos humanos para a sua educação. Muitas vezes, "se o filho não tem sucesso é o balanço da empresa familiar que se torna negativo. Eles [os filhos] são condenados ao sucesso para evitar a falência" (Gaulejac, 2007, p. I83).

Mansano (2003) diz que nas regras classificatórias para a escolha da profissão há uma codificação da vida especialmente dos jovens, facilitando a intervenção de dispositivos de controle tanto sobre o cotidiano do jovem quanto sobre suas escolhas profissionais. A demanda social por uma escolha profissional dos jovens provém das mais variadas fontes: dos pais, dos professores e dos amigos. Essas trajetórias, por vezes, são sentidas pelos jovens como desconectadas de suas vidas, especialmente porque eles acabam escolhendo as profissões tidas como as mais seguras e rentáveis e não permitem ao jovem experimentar as diferentes possibilidades profissionais. Desse modo, tanto os adolescentes como os adultos vêm se subjetivando na esfera da escolha profissional.

\section{CONSIDERAÇÕES FINAIS}

Como resultados dessa pesquisa, percebeu-se que as relações familiares carecem de afeto, de relações íntimas, uma vez que são invadidas pela consequência 
que traz o trabalho imaterial, ou seja, pela rentabilização do tempo, tanto de vida, quanto de trabalho.

As consequências decorrentes dessa responsabilização de si pela carreira recaem sobre e diretamente se refletem na família dos executivos bancários, que passam também a sofrer e usufruir da carreira deles.

Há um excesso de atividades de que o executivo tem de dar conta e que não é possível realizar somente no tempo e local de trabalho. Esse excesso é levado para casa, onde a relação familiar é a principal afetada. Afora isso, as redes de relacionamento que o executivo deve manter fora do trabalho extrapolam para o horário de convívio familiar, requerendo, na perspectiva do trabalho imaterial, sua vitalidade e entrega que diz respeito a estar, fora do horário de trabalho, em eventos sociais. Os resultados apontaram a falta de convívio com a família, uma vez que ofertar tempo para os familiares seria deixar de estar nessa promissora rede de relacionamentos diretamente associada ao sucesso profissional. Tais considerações permitem afirmar desde já que a carreira também tem seu lado perverso, uma vez que as pessoas excluídas da rede de relacionamentos veem suas carreiras afetadas negativamente e, por isso, acabam excluídas do círculo empresarial.

Quando não há mais o que fazer, advém a resignação em relação à família e suas atividades domésticas, em especial, porque o sujeito do trabalho não vê a possibilidade de se colocar à margem das obrigações condizentes com a carreira. Por isso, certos dilemas têm implicações não apenas na precarização do trabalho, mas também na precarização da vida (Bauman, 2007a). Desentendimentos no núcleo familiar, corroborando com Gravina (2002), também fazem parte das consequências dos dilemas dos executivos bancários.

Assim, o trabalho mostra-se como dispositivo potente de subjetividade. Com base no olhar da família acerca dos dilemas vivenciados pelos executivos bancários, observaram-se estilos de vida que condizem com a vida líquida da sociedade líquido-moderna.

Os estilos de vida já cristalizados e subjetivados pelos membros de suas relações familiares dizem respeito e estão associados ao uso intensivo da tecnologia, à potencialização dos relacionamentos firmados no e fora do trabalho, à mobilidade e ao consumo. Esta configuração está relacionada a um "modelo" de carreira profissional meteórica, de responsabilidade única do próprio trabalhador, em um contexto em que prevalece o trabalho imaterial (Lazzarato \& Negri, 200I).

O preço pago pelos executivos bancários, assim como pelos membros de suas relações familiares, foram relativos à convivência familiar que se mostrou, na pesquisa, visivelmente prejudicada, especialmente pela intimidade familiar invadida pelo trabalho e pelo mal-estar que se manifestaram nos adoecimentos. 
Os horários irregulares, trabalhos noturnos, desorganização da vida familiar e de seus ritmos biológicos revertem-se na desregulamentação da vida da família inteira. A "falsa" liberdade que pressupõe ser "gestor de si" recai diretamente na família.

Esta pesquisa ratifica e avança os achados de Tanure et al. (2007) em relação ao sofrimento que a carreira traz aos executivos e contribui no sentido de possibilitar a compreensão da dinâmica dos dilemas da condução da carreira e seus desdobramentos para a família. A família também sente responsabilidade sobre a condução da carreira do executivo bancário. O sofrimento que assola o executivo bancário torna-se também sofrimento da família. A carreira dos filhos, inclusive, passa a ser gerenciada pelos pais numa perspectiva de que os filhos tornem-se aptos para as demandas do trabalho imaterial. A lógica de preservação e de continuidade de um estilo de vida que serve aos objetivos do capital se vê nessa conduta plenamente contemplada.

A pesquisa mostrou-se oportuna e pertinente uma vez que, além de ratificar os achados de Tanure et al. (2007), apresenta avanços em relação aos estudos sobre carreiras. Tais avanços referem-se especialmente à forma de se abordar o tema, já que se inseriram nesta pesquisa aqueles que sofrem as repercussões da vivência de dilemas por parte dos executivos bancários, que, em geral, fazem suas escolhas em prol do projeto organizacional.

Adicionalmente, observou-se, a partir das vozes que ecoaram os dilemas dos executivos bancários, que toda a família é afetada. Essa afetação envolve: o espaço da casa danificado pela realização do trabalho; a intimidade das relações familiares que se mostram precarizadas; e a reprodução desse modelo na forma de conduzir a carreira dos filhos. O equilíbrio entre vida profissional e pessoal, portanto, diferentemente do que apresentam alguns autores nos estudos sobre carreira (Baruch, 2006; Challiol, 2004; Mainiero \& Sullivan, 2005; Sullivan \& Mainiero, 2007; Tremblay, 2005), é um mito.

\section{CAREER AND FAMILY IN THE MODERN-LIQUID SOCIETY}

\section{ABSTRACT}

This article stems from an exploratory research which aimed to discern the personal dilemmas related to the banking executives' career are currently shaped and understand how these dilemmas are twisted with their family relationships. In order to do so, to theoretically support, the following concepts were taken up: 
dilemma, subjectivity and life style, career, especially in the light of the models of borderless and protean career and immaterial work. The interviews were conducted with fourteen representatives from the family of the banking executives. The structured interviews were conducted with the family members in their homes or in stores suggested by them. Data were analyzed in a qualitative way. Results suggest the existence of dilemmas related to spatial and functional mobility and social life dispossession. The existence of these dilemmas is not a novelty. However, nowadays they take over the individual's professional and personal lives regardless of time and space limits. This, in turn, affects the executive and his family's way of life. Such configuration is connected to a "model" of meteoric professional career, which is the responsibility of the worker alone, in a context where immaterial work prevails. Whatever the choice of the executive and the family, both suffer the consequences of their decisions. Under the metaphor of modern-liquid society, it was possible to reflect on the theme of the fluidity of existence and thus consider the construction of career paths also as liquid, fluid, sinuous. The metaphor of sinuosity allowed to think that the construction of career may be uncertain, insecure and vulnerable. The results also showed the lack of contact with the family since offering family time would no longer be in this promising relationship network directly linked to professional success. Thus, from the look of the family about the dilemmas experienced by bankers, it was observed lifestyles that are associated with liquid-modern society.

\section{KEYWORDS}

Career. Dilemmas. Banking executive. Family relations. Lifestyle.

\section{CARRERA Y FAMILIA EN LA SOCIEDAD LÍQUIDO-MODERNA}

\section{RESUMEN}

Este artículo pretende comprender cómo aquellas personas que componen las relaciones familiares de ejecutivos bancarios entienden los dilemas personales relativos a la carrera de estos últimos, así como también analizar qué estilos de vida son resultados del desarrollo de la carrera de ejecutivos bancarios en el contexto de trabajo inmaterial. Para esto, en términos teóricos y con el objetivo de sustentarlo, se trabajó con los conceptos de dilema, subjetividad y estilos de vida, los modelos sin fronteras y de trabajo inmaterial. Entrevistamos a catorze repre- 
sentantes de sus relaciones familiares. Se realizaron entrevistas estructuradas con miembros de la familia en sus casas o en los negócios que ellos indicaron. El análisis de datos fue realizado de forma cualitativa. Los resultados indicaron dilemas relativos a la movilidad espacial y funcional y a la privación de la vida. La existencia de los dilemas no se mostro inédita, sin embargo, en la contemporaneidad, ellos toman a vida profesional y personal de los sujetos independientemente de limites espacio-temporales, afectando el modo de vivir del ejecutivo bancario y de su familia. Esta configuración está relacionada a un "modelo" de carrera profesional meteórica, de responsabilidad única del proprio trabajador, en un contexto que prevalece el trabajo inmaterial. Sea cual sea la elección del ejecutivo y de la familia, ambos sufren las consecuencias de sus decisiones. Bajo la metáfora de la vida líquida, por lo que fue posible reflexionar sobre el tema de la fluidez de la existencia y por lo tanto considerar la construcción de caminos de la carrera también líquido, sinuosa. La metáfora de la sinuosidad permite pensar que la construcción de la carrera puede ser incierto, inseguro y vulnerable. Los resultados también mostraron que la falta de contacto con la família esta directamente relacionada con el éxito profesional. Así, desde la mirada de la familia acerca de los dilemas experimentados por los banqueros, los estilos de vida observadas se cumple en la sociedad líquida moderna red de la vida.

\section{PALABRAS CLAVE}

Carrera profesional. Dilemas. Ejecutivo bancario. Relaciones familiares. Estilos de vida.

\section{REFERÊNCIAS}

56 atitudes infalíveis para fortalecer sua carreira. (2009). Você S.A., ed. I28.

Arthur, M., Hall, D., \& Lawrence, B. (1989). Generating new directions in career theory: the case for a transdisciplinary approach. In M. Arthur, D. Hall, \& B. Lawrence (Orgs.). Handbook of career theory (pp. 7-25). Cambridge: Cambridge University Press.

Arthur, M., \& Rousseau, D. (200I). The boundaryless career: a new employment principle for a new organizational era. Oxford: Oxford University.

Baruch, Y. (2004a). Transforming careers: from linear to multidirectional career paths. Career Development International, (9), 58-73.

Baruch, Y. (2004b). Managing careers: theory and practice. Harlow: Financial Times Prentice Hall. Baruch, Y. (2006). Carrer development in organizations and beyond: balancing traditional and contemporary viewpoints. Human Resource Management Review, 16, I25-138.

Bauman, Z. (2003). Comunidade. Rio de Janeiro: Jorge Zahar. 
Bauman, Z. (2004). Amor líquido: sobre a fragilidade dos laços humanos. Rio de Janeiro: Jorge Zahar. Bauman, Z. (2007a). Vida líquida. Rio de Janeiro: Jorge Zahar.

Bauman, Z. (2007b). Tempos líquidos. Rio de Janeiro: Jorge Zahar.

Bauman, Z. (2009). A arte da vida. Rio de Janeiro: Jorge Zahar.

Briscoe, J., \& Hall, D. (2006). The interplay of boundaryless and protean careers: combinations and implications. Journal of Vocational Behavior, 69, 4-I8.

Briscoe, J., Hall, D., \& Demuth, F. (2006). Protean and boundaryless careers: an empirical exploration. Journal of Vocational Behavior, 69, 30-47.

Challiol, H. (2004). Gestion de carrière des individus em couple à double carrière. In S. Guerrero, J. L. Cerdin, \& A. Roger (Orgs.). La gestión des carrières: enjeux et perspectives (pp. 25-47). Montreal: AGRH.

Chanlat, J. F. (2005). Mitos e realidades sobre o estresse dos gerentes. In E. Davel, \& M. C. Mello (Orgs.). Gerência em ação: singularidades e dilemas do trabalho gerencial (pp. 28I-3I2). São Paulo: Editora FGV.

Coragem para mudar. (2008). Exame, ed. 934.

Costa, F. P., \& Honório, L. C. (2009). Fatores de pressão no trabalho e estratégias de combate ao estresse ocupacional: avaliando os gerentes de uma usina siderúrgica brasileira. Anais do Encontro de Gestão de Pessoas e Relações de Trabalho, Curitiba, PR, Brasil.

Davel, E., \& Melo, M. C. (2005). Gerência em ação: singularidades e dilemas do trabalho gerencial. São Paulo: Editora FGV.

Dejours, C. (2004). Addendum: da psicopatologia à psicodinâmica do trabalho. In S. Lancman, \& L. I. Sznel War (Orgs.). Chistophe Dejours: da psicopatologia à psicodinâmica do trabalho (pp. 47-IO4). Brasília: Editora Fiocruz.

Dutra, J. de S. (Org.). (2010). Gestão de carreiras na empresa contemporânea. São Paulo: Atlas.

Executivos de sucesso. (2008). Exame, ed. 928.

Febraban. O setor bancário em números. Recuperado em 5 outubro, 2008, de http://www.febraban. org.br/Febraban.asp.

Febraban. Objetivos estratégicos permanentes. Recuperado em i5 janeiro, 20I0, de http://www. febraban.org.br/Febraban.asp.

Ferreira Neto, J. L. (2000). Subjetividades contemporâneas: algumas contribuições de Deleuze. Plural, 6(13), I05-II3.

Fontenelle, I. A. (2005). "Eu Proteu": a autogestão de carreira entre fatos e mitos. Anais do Encontro Nacional dos Programas de Pós-Graduação em Administração, Brasília, DF, Brasil.

Gaskell, G. (2003). Entrevistas individuais e grupais. In M. Bauer, \& G. Gaskell (Orgs.). Pesquisa qualitativa com texto, imagem e som: um manual prático (pp. 64-89). Petrópolis: Vozes.

Gaulejac, V. (2007). Gestão como doença social. São Paulo: Ideias e Letras.

Gravina, M. E. R. (2002). LER - Lesões por Esforços Repetitivos: uma reflexão sobre os aspectos psicossociais. Saúde e Sociedade, 11(2), 65-87.

Grisci, C. L. I. (2008). Trabalho imaterial, controle rizomático e subjetividade no novo paradigma tecnológico. RAE Eletrônica, 7(I).

Grisci, C. L. I., \& Bessi, V. G. (2004). Modos de trabalhar e de ser na reestruturação bancária. Sociologias, 6(12), I60-200. 
Grisci, C. L. I., Hofmeister, P., \& Cigerza, G. (2006). Trabalho imaterial, controle e subjetividade na reestruturação produtiva bancária. In V. C. Piccinini, L. Holzman, I. Kovacs, \& V. Guimarães (Orgs.). O mosaico do trabalho na sociedade contemporânea: persistências e inovações (pp. 245-270). Porto Alegre: Editora UFRGS.

Guattari, F., \& Rolnik, S. (2005). Micropolítica: cartografias do desejo. Petrópolis: Vozes.

Guillaume, C., \& Pochic, S. (2007). What would you sacrifice? Access to top management and the worklife balance. Gender, Work and Organization, 16(I), I435.

Hall, D. (I996). Protean careers of the 2Ist century. Academy of Management Executive, 10(4), 8-16. Holzmann, L. (2006). Divisão sexual do trabalho. In A. D. Cattani, \& L. Holzmann (Orgs.). Dicionário de trabalho e tecnologia (pp. IOI-IO3). Porto Alegre: Editora UFRGS.

Lazzarato, M., \& Negri, A. (200I). Trabalho imaterial: formas de vida e produção de subjetividade. Rio de Janeiro: DP\&A.

Mainiero, L., \& Sullivan, S. (2005). Kaleidoscope careers: an alternative explanation for the opt-out revolution. Academy of Management Executive, 19(I), Io6-I23.

Mansano, S. R. V. (2003). Vida e profissão: cartografando trajetórias. São Paulo: Summus.

Merlo, Á. R. C., \& Barbarini, N. (2002). Reestruturação produtiva no setor bancário brasileiro e sofrimento dos caixas executivos: um estudo de caso. Psicologia a Sociedade, 14(I), IO3-I22.

Minayo, M. C. de S. (Org.). (200I). Pesquisa social: teoria, método e criatividade. Petrópolis: Vozes.

Mundo sem fronteiras. (2008). Exame, ed. 922.

Netz, S. R. (2005). Novas tecnologias da informação: suas influências no trabalho bancário. Anais do Congresso Brasileiro de Sociologia, Belo Horizonte, MG, Brasil.

Rosenfield, C. (2004). Autonomia outorgada e apropriação do trabalho. Sociologias, 6(ı2).

Santos, M. A. F., Siqueira, M. V. S., \& Mendes, A. M. Imaginário organizacional e sofrimento no trabalho: um estudo de caso no setor bancário. Anais do Encontro de Gestão de Pessoas e Relações de Trabalho, Curitiba, PR, Brasil.

Scanfone, L., Carvalho Neto, A., \& Tanure, B. Tempos de trabalho e de não trabalho: o difícil equilíbrio do alto executivo entre a carreira, as relações afetivas e o lazer. Anais do Encontro Nacional dos Programas de Pós-Graduação em Administração, Rio de Janeiro, RJ, Brasil.

Segnini, L. R. P. (I999). Reestruturação nos bancos no Brasil: desemprego, subcontratação e intensificação do trabalho. Educ. Soc., 20(67), p. 183-209.

Seja o talento que o mercado procura. (2008). Você S.A., ed. r2o.

Sennett, R. (2006). A cultura do novo capitalismo. Rio de Janeiro: Record.

Sua carreira em 2009. (2009). Você S.A., ed. I27.

Sullivan, S., \& Arthur, M. (2006). The evolution of the boundaryless career concept: examining physical and psychological mobility. Journal of Vocational Behavior, (69), 19-29.

Sullivan, S., \& Mainiero, L. (2007). Kaleidoscope careers: benchmarking ideas for fostering family-friendly workplaces. Organizational Dynamics, 36(I), 45-62.

Tanure, B., Carvalho Neto, A., \& Andrade, J. A superexecutiva às voltas com carreira, relógio biológico, maternidade, amores e preconceitos. Anais do Encontro Nacional dos Programas de Pós-Graduação em Administração, Salvador, BA, Brasil.

Tanure, B., Carvalho Neto, A., \& Andrade, J. (2007). Executivos: sucesso e (in)felicidade. Rio de Janeiro: Elsevier. 
Tremblay, D. (2005). Gerentes e a conciliação entre trabalho e família. In E. Davel, \& M. C. Mello (Orgs.). Gerência em ação: singularidades e dilemas do trabalho gerencial (pp. 83-Io7). São Paulo: Editora FGV.

Vazquez, A. C., Oltramari, A. P., Tonon, L., \& Garay, A. B. S. (2010). Desempenho e carreira: um panorama da produção acadêmica no período de 2000 a 2008 na administração brasileira. Anais do Encontro Nacional dos Programas de Pós-Graduação em Administração, Rio de Janeiro, RJ, Brasil. Veloso, E. F. R., Dutra J. S., Fischer, A. L., Pimentel, J. E. A., \& Cunha da Silva, R. Relação entre a adoção de práticas de gestão de carreira e a percepção sobre o crescimento profissional: um estudo com empresas atuantes no mercado brasileiro. Anais do Encontro de Gestão de Pessoas e Relações de Trabalho, Curitiba, PR, Brasil.

Virilio, P. (I996). Velocidade e política. São Paulo: Estação Liberdade.

Zilio, L. B., \& Dellagnelo, E. H. A expatriação como prática de desenvolvimento de pessoas nas organizações: um estudo da política de expatriação de uma multinacional francesa. Anais do Encontro Nacional dos Programas de Pós-Graduação em Administração, Rio de Janeiro, RJ, Brasil. 